\title{
ANTIOXIDANT ACTIVITY OF TAUCO ETHANOL EXTRACT AND ITS FRACTIONS
}

\author{
RESMI MUSTARICHIE ${ }^{1 *}$, SANDRA MEGANTARA ${ }^{1}$, WIWIEK INDRIYATI ${ }^{1}$, ADE ZUCHROTUN ${ }^{2}$
}

${ }^{1}$ Department of Pharmaceutical Analysis and Medicinal Chemistry, Faculty of Pharmacy, Universitas Padjadjaran, Indonesia. ${ }^{2}$ Department of Biological, Faculty of Pharmacy, Universitas Padjadjaran, Indonesia. Email: resmi.mustarichie@unpad.ac.id

Received: 21 October 2016, Revised and Accepted: 30 January 2017

ABSTRACT

Objective: The objective of this study is to investigate antioxidant activity and phytochemical screening of ethanol extract, fractions of water, ethyl acetate, and n-hexane from tauco.

Methods: Two types of tauco were extracted using soxhletation methods, followed by fractionation using liquid-liquid extraction methods, and phytochemical screening. Antioxidant activity test was carried out using 1,1-diphenyl-2-pikrilhiradzil with ascorbic acid (vitamin C) as a reference. Modified method of Farnsworth was applied for phytochemical screening.

Results: It was found that extracts of ethanol and ethyl acetate fraction containing flavonoids, monoterpenoid, and sesquiterpenoids whereas the water fraction and a fraction of n-hexane only contain monoterpenes and sesquiterpenoids. The inhibition concentration 50 (IC $_{50}$ value for the ethanol extract, water, ethyl acetate, and n-hexane fractions of two taucos in a row were $1192.71 \mathrm{ppm}, 1746.01 \mathrm{ppm}, 722.38 \mathrm{ppm}, 1845.45 \mathrm{ppm}$ and 1190.15 ppm, 1740.30, 710.46, for tauco A and B, respectively.

Conclusion: It was unexpected that tauco ethanol extract and fractions showed much weaker antioxidant activity than vitamin $\mathrm{C}$, which had the $\mathrm{IC}_{50}$ value of $4.41 \mathrm{ppm}$

Keywords: Antioxidant, Flavonoid, Free radicals, 1,1-diphenyl-2-pikrilhiradzil, Tauco, Ascorbic acid.

(C) 2017 The Authors. Published by Innovare Academic Sciences Pvt Ltd. This is an open access article under the CC BY license (http://creativecommons. org/licenses/by/4. 0/) DOI: http://dx.doi.org/10.22159/ajpcr.2017.v10s2.19488

\section{INTRODUCTION}

Tauco is one of the traditional food items that come from Indonesia and are found especially in the area of West Java. Tauco paste form, can be found, in the form tauco dry and wet. Tauco is processed soy products obtained from fermentation techniques. This fermentation tauco aims to improve taste, but it also can improve the nutritional content contained in soy. Tauco society generally used as food flavoring agent [1]. Tauco generally made of yellow soybeans. Soybean crops including a group of natural flavonoid that isoflavone group. Soybeans are known to have biological activity as an antioxidant, estrogenic effects, antiosteoporosis, and anticancer [2]. Isoflavones are antioxidants that are needed by the body to stop the reaction of free radical formation [3]. Isoflavone glycosides are a major component in soybean and non-fermented soy products, while the soybean fermented product is found free isoflavones (aglycone) in large quantities [4]. Based on research that has been done Hutriadi [5], tauco compounds containing daidzein and genistein. Genistein and daidzein are included in the free isoflavone compounds formed from the fermentation process soybeans [6]. Genistein is the most powerful antioxidant in soy, followed by daidzein [7].

Antioxidants are compounds that have the ability to protect cells and tissues from damage caused by the threat of the presence of free radicals that are reactive [8]. Antioxidants react with free radicals to form nonradical compounds are relatively stable [9]. Whether or not strong antioxidant activity can be seen from the inhibition concentration 50 $\left(\mathrm{IC}_{50}\right)$ value. $\mathrm{IC}_{50}$ is a number that indicates the concentration of extract that can inhibit the oxidation of $50 \%$. The smaller the $\mathrm{IC}_{50}$ value, the higher the antioxidant activity [10]. Research into the antioxidant activity in soybean has been conducted, but research on the antioxidant activity in soybean fermented product has not been done, particularly in tauco. Therefore, it, in this study, will be conducted research on the antioxidant activity assay method tauco with 1,1-diphenyl-2pikrilhiradzil (DPPH) with ascorbic acid as a reference. Part of this study has been published in Indonesia [11].

\section{METHODS}

Collecting materials and pre-treatment sample

Two well-known brands tauco sample used in this study were obtained from a supermarket in the area of Bandung, West Java. Tauco dried using an oven at $60-70^{\circ} \mathrm{C}$ until constant weight.

\section{Extraction and fractionation tauco}

The extraction method used in this research was the method soxhletation using ethanol 96\%. The extraction followed standard soxhletation method [12-14]. It was done approximately 4 hrs or until almost colorless solvent droplets. Viscous liquid extract obtained was then evaporated to obtain a thick extract with constant.

$$
\% \text { Yield }=\frac{\text { Extract weight }}{\text { Sample weight }} \times 100 \%
$$

Water content of the obtained extract was determined to make sure fulfill Farmakope Herbal requirement, in which the water content in the extract should not be more than $10 \%$ to avoid the rapid growth of fungi and microorganisms in the extract [15].

\section{Hydrolysis of isoflavones}

Hydrolysis aims to separate the intermediate compounds with glycosides aglycone. $10 \mathrm{~g}$ tauco extract dissolved in a mixture of methanol and $2 \mathrm{~N}$ hydrochloric acid in the ratio 1:1, refluxed in water bath for $2 \mathrm{hrs}$ at a temperature of $40^{\circ} \mathrm{C}$. After refluxing, the mixture was evaporated with a rotary evaporator at a temperature of $40^{\circ} \mathrm{C}$ to remove methanol.

\section{Fractionation}

Fractionation performed using liquid-liquid extraction. Extracts tauco hydrolyzed then fractionated using a solvent of water, ethyl acetate, and n-hexane. The results of the water fraction, fraction of ethyl acetate and $n$-hexane fraction were then evaporated with a rotary evaporator. 
Phytochemical screening

Phytochemical screening was conducted on a sample tauco to determine the content of secondary metabolites contained therein based on Farnsworth method [16] which includes:

a. Identification of alkaloids

b. Identification of compounds polifenolat

c. Identification tanin

d. Identification flavonoids

e. Identification monoterpenoid and sesquiterpenoids

f. Identification of Steroids and triterpenoid

g. Identification quinone

h. Identification of saponin.

\section{Thin layer chromatography (TLC)}

TLC plates (stationary phase) used were silica gel GF254. TLC plates prepared with a size of $10 \times 4 \mathrm{~cm}$. Based on research conducted by Irianti et al. [17], the developer used is toluene:ethyl acetate:acetic acid at a ratio of 5:4:1. Subsequently observed in ultraviolet (UV) $254 \mathrm{~nm}$ and $366 \mathrm{~nm}$. Spotting observed marked for the calculated value of Rf. To test qualitatively antioxidants which had been spotted TLC plate tauco extracts and fractions sprayed with DPPH. DPPH solution was prepared by dissolving reagent DPPH as much as $4 \mathrm{mg}$ in $50 \mathrm{ml}$ of $96 \%$ ethanol. Furthermore, the observed color staining formed.

\section{Antioxidant activity test}

Test of antioxidant activity with DPPH based on Molyneux method $[18,19]$ with ascorbic acid as a reference. The test includes:

1. Preparation of the test solution.

2. Determination of the wavelength $(\lambda)$ maximum DPPH

DPPH solution of $3 \mathrm{ml}$ of ethanol was added $2 \mathrm{ml}$, homogenized, and observed absorbance at a wavelength of 450-650 $\mathrm{nm}$. The maximum wavelength of absorption characterized by the greatest. Blank of ethanol was used.

3. Determination of operating time DPPH solution in ethanol.

4. Determination of the sample incubation time.

5. The determination of $\mathrm{IC}_{50}$ values of samples.

A total of $2 \mathrm{ml}$ of test solution in various concentrations added about $3 \mathrm{ml}$ of DPPH solution, homogenized, and then allowed to stand. Absorbance was read at maximum wavelength was $517 \mathrm{~nm}$. Used as a blank test solution. For testing the reference solution, as many as $2 \mathrm{ml}$ of vitamin C in various concentrations added about $3 \mathrm{ml}$ of DPPH solution, homogenized, and then allowed to stand. Absorbance is read at maximum wavelength is $517 \mathrm{~nm}$. As a form of ascorbic acid solution was used in various concentrations as much as $2 \mathrm{ml}$ and $3 \mathrm{ml}$ of ethanol as much. $\mathrm{IC}_{50}$ values were calculated from a linear regression curve between the \% inhibition of uptake with various concentrations of extracts of the test solution with the following formula:

$$
\% \text { Inhibition }=\left[1-\left(\frac{A_{\text {test }}}{A_{\text {control }}}\right)\right] \times 100 \%
$$

Where

$A_{\text {test }}=$ absorbance of DPPH solution in the sample

$A_{\text {control }}=$ absorbance of DPPH solution in ethanol $(3 \mathrm{ml} \mathrm{DPPH}$ and $2 \mathrm{ml}$ of ethanol).

Data were obtained as percent inhibition values that were plotted against the concentration of test solution. $\mathrm{IC}_{50}$ describe extract concentration required to inhibit $50 \%$ of DPPH radical activity. $\mathrm{IC}_{50}$ value obtained from the graph the concentration of the extract of the percent inhibition of DPPH.

\section{RESULTS AND DISCUSSION}

Collection results materials and pre-treatment samples

Two samples tauco soybeans, namely, Tauco A and B, from two wellknown commercially brands obtained from Bandung, West Java. The water content in tauco was high enough so that samples need to be dried to remove the water content contained therein. Two taucos as much as $2.25 \mathrm{~kg}$ sample dried using an oven at a temperature of $70^{\circ} \mathrm{C}$ until constant weight was obtained, which was 832.55 and $830.00 \mathrm{~g}$. The water content contained in tauco $37 \%$

\section{Extraction and fractionation}

Tauco dried samples were extracted using methods soxhletation. The soxhletation method will occur repeatedly so that the extraction process will be more perfect. Soxhletation method was done because it was known that the active compounds contained in tauco were thermostable. In addition, the soxhletation method's number of samples and solvents needed just a little so that the extraction process will be more efficient.

A total of $300 \mathrm{~g}$ of dried tauco obtained viscous extract of 88.45 and $90 \mathrm{~g}$ for Tauco A and B, respectively. We found that the water content in both tauco samples fulfilled Farmakope Herbal Indonesia requirement that was below $10 \%$ [15].

The viscous extract obtained was then hydrolyzed to break down into its component isoflavone glycosides and isoflavone glycosides free (aglycone). A total of $10 \mathrm{~g}$ of viscous extract hydrolyzed using $\mathrm{HCl}$ and methanol at a ratio of 1:1. Hydrolysis process is carried out for $2 \mathrm{hrs}$ at a temperature of $40^{\circ} \mathrm{C}$ with the aim of accelerating the termination reaction force of the component isoflavone glycosides. Hydrolysis was then evaporated using a rotary evaporator to remove the methanol solvent. The residue was then fractionated to attract the active compound contained in the extract based on the level of polarity. Fractionation was conducted using liquid-liquid extraction using a solvent of water, ethyl acetate, and n-hexane.

\section{Phytochemicals screening results}

Phytochemical screening was conducted to determine the content of secondary metabolites contained in the extract and the fractions tauco. The phytochemical screening results are shown in Table 1.

Table 1 showed that the tauco samples, extracts of ethanol and ethyl acetate fraction containing flavonoids, monoterpenoid and sesquiterpenoids, and saponin. While the water fraction and a fraction of $n$-hexane only contain monoterpenes and sesquiterpenoids. This result comparable to photo screening result of soybean (Glycine soja Sieb. and Zucc.) [20], except for tannin. In this result, we did not find tannin content in our samples. It might be due to soybean used and or mixed soybean and other beans were used in making the tauco.

\section{Results of TLC}

TLC was carried out using the developer toluene:ethyl acetate:acetic acid $(5: 4: 1)$. Extracts and fractions tauco observed in visible light, UV $254 \mathrm{~nm}, 366 \mathrm{~nm}$ UV, and spotting DPPH solution. Some TLC results are shown in Fig. 1 and Table 2.

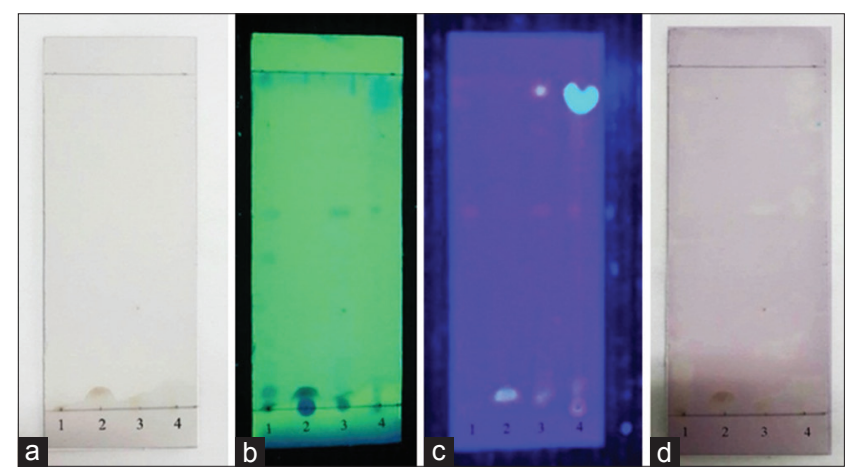

Fig. 1: Thin layer chromatography by the developer toluene:ethyl acetate:acetic acid (5:4:1) of Tauco A. 1 - Ethanol extract, 2 - Water fraction, 3 - Ethyl acetate fraction, 4 - N-hexane fraction. a - visible light, b - ultraviolet $254 \mathrm{~nm}, \mathrm{c}$ - ultraviolet $366 \mathrm{~nm}, \mathrm{~d}$ - DPP solution 
Table 1: Phytochemical screening results

\begin{tabular}{|c|c|c|c|c|c|c|c|c|c|c|}
\hline \multirow[t]{2}{*}{ Secondary metabolites } & \multicolumn{2}{|c|}{ Tauco samples } & \multicolumn{2}{|c|}{ Ethanol extract } & \multicolumn{2}{|c|}{ Water fraction } & \multicolumn{2}{|c|}{$\begin{array}{l}\text { Ethyl acetate } \\
\text { fraction }\end{array}$} & \multicolumn{2}{|c|}{ n-heksana fraction } \\
\hline & Tauco A & Tauco B & Tauco A & Tauco B & Tauco A & Tauco B & Tauco A & Tauco B & Tauco A & Tauco B \\
\hline Polyphenols & - & - & - & - & - & - & - & - & - & - \\
\hline Tannin & - & - & - & - & - & - & - & - & - & - \\
\hline Flavonoids & + & + & + & + & - & - & + & + & - & - \\
\hline $\begin{array}{l}\text { Monoterpenoid and } \\
\text { sesquiterpenoid }\end{array}$ & + & + & + & + & + & + & + & + & + & + \\
\hline Steroids & - & - & - & - & - & - & - & - & - & - \\
\hline Triterpenoid & - & - & - & - & - & - & - & - & - & - \\
\hline Quinone & - & - & - & - & - & - & - & - & - & - \\
\hline Saponin & + & + & + & + & + & + & + & + & - & - \\
\hline
\end{tabular}

+: Detected, -: Not detected

Table 2: TLC of ethanol extract and its fractions of Tauco A and B

\begin{tabular}{lllll}
\hline Sample & Rf & Visible light & UV 254 nm & UV 366 nm \\
\hline Ethanol extract & 0.57 & - & Blue & Green \\
Water fraction & 0.91 & - & - & Green \\
Ethyl acetate fraction & 0.06 & - & Blue & Yellow \\
& 0.57 & - & Blue & Yellow \\
N-hexane fraction & 0.85 & - & Blue & Green \\
& 0.95 & - & Blue & Yellow \\
& 0.58 & - & Blue & Yellow \\
\hline
\end{tabular}

DPPH: 1,1-diphenyl-2-pikrilhiradzil, UV: Ultraviolet, TLC: Thin layer chromatography, -: Not detected

TLC carried out as an early detection of antioxidant activity in the sample. DPPH solution was used as spotting patches to determine whether or not the compounds that had antioxidant activity in extracts and fractions of tauco. Their antioxidant activity characterized by the formation of patches of yellow with a purple background. Both Tauco A and $\mathrm{B}$ found to have this color.

\section{Determination of wavelength maximum DPPH}

DPPH solution color change time is reduced by antioxidants can be measured by using UV-visible spectrophotometry at a wavelength of 515-520 nm (Molyneux, 2004). For this work, it was found the DPPH solution maximum absorption at a wavelength of $517 \mathrm{~nm}$.

Determination of time operating results DPPH solution in ethanol DPPH solution is unstable, so it is necessary to determine the operating time DPPH. Determining operating time was done to determine the best working time of DPPH solution. Graph DPPH operating time can be seen in Fig. 2.

Fig. 2 showed that the optimum time of DPPH work is in the 35th to 50 th minutes where at this time there was no significant increase or decrease in absorbance.

\section{Determination of sample incubation time}

Determination of the sample incubation time was needed to see the time it took the test sample, the ethanol extract, the water fraction, fraction of ethyl acetate and n-hexane fraction of tauco be reacted with DPPH, characterized by a steady uptake. The timing of incubation was also done on samples of the comparison, namely, vitamin C. The timing of incubation samples was done in 5 minutes intervals for 2 hrs at a wavelength of $517 \mathrm{~nm}$. It found that the incubation time the ethanol extract tauco, namely, in the $70^{\text {th }}$ minutes to the $80^{\text {th }}$ minutes, the incubation time the water fraction of tauco, namely, in the $100^{\text {th }}$ minutes until the $110^{\text {th }}$ minutes, the incubation time ethyl acetate fraction of tauco, namely, in the $85^{\text {th }}$ minutes to the $95^{\text {th }}$ minutes, and the incubation time $\mathrm{n}$-hexane fraction of tauco, namely, in the $75^{\text {th }}$ minutes to the $85^{\text {th }}$ minutes. As for ascorbic acid C incubation period was from the $30^{\text {th }}$ minutes until the $40^{\text {th }}$ minutes.

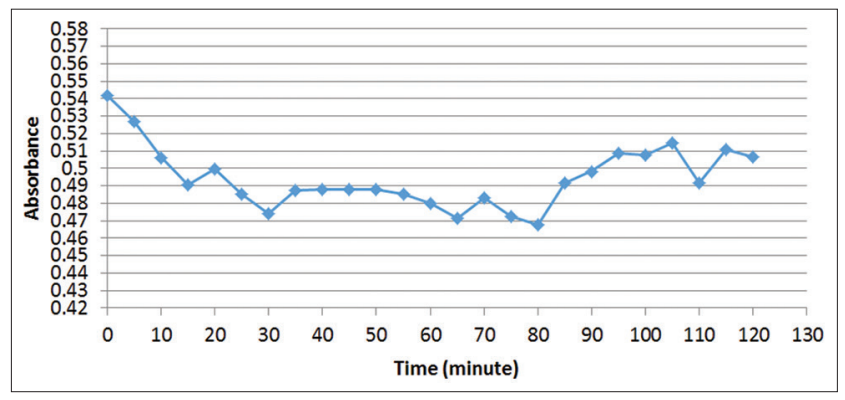

Fig. 2: 1,1-diphenyl-2-pikrilhiradzil operating time

\section{Determination of IC ${ }_{50}$ sample}

In this study, each sample weighed $50 \mathrm{mg}$ and dissolved in $50 \mathrm{ml}$ volumetric flask, so we get the mother liquor with a concentration of $1000 \mathrm{ppm}$. The mother liquor was then diluted to $100,200,300,400$, and $500 \mathrm{ppm}$. DPPH solution was prepared by weighing $2 \mathrm{mg}$ DPPH dissolved in $50 \mathrm{ml}$ volumetric flask, so we get a DPPH solution with a concentration of $40 \mathrm{ppm}$. As a reference used ascorbic acid as vitamin C is known to have very powerful antioxidant activity. Vitamin C can donate a hydrogen atom to stabilize free radicals and can prevent a chain reaction.

The parameters used in the test the antioxidant activity by DPPH method were $\mathrm{IC}_{50}$, i.e., the concentration where the sample was able to reduce $50 \%$ of the initial concentration of DPPH activity. IC $_{50}$ value of the samples obtained using the linear regression equation that states the relationship between the concentrations on the $\mathrm{X}$ axis the percent inhibition on the $Y$ axis. Testing the absorbance of each sample at various concentrations carried out at a wavelength of $517 \mathrm{~nm}$ is then calculated percent inhibition values of each sample. The greater the concentration used, the greater the reduction of free radical activity (\% inhibition). Samples which act as antioxidants will donate hydrogen atoms to the radical DPPH. DPPH radical reduction will experience characterized by a color change from purple to yellow. When the color changes, then there will be a decrease in the absorbance of DPPH. The greater the 
concentration of the sample used, the greater the ability of antioxidants to reduce DPPH. Measured absorbance decreases with an increase in concentration of the sample. Hence, the greater the concentration of the sample is used, then the greater the percent inhibition of the sample.

Value percent inhibition of each test solution and reference solution at various concentrations is used to create the linear regression equation. $\mathrm{IC}_{50}$ value of ethanol extract, the water fraction, fraction of ethyl acetate, and n-hexane fraction of each tauco in a row was $1192.71 \mathrm{ppm}$, $1746.01 \mathrm{ppm}, 722.38 \mathrm{ppm}, 1845.45 \mathrm{ppm}$ and $1190.15 \mathrm{ppm}, 1740.30$, 710.46 , for Taucho A and $\mathrm{B}$, respectively. $\mathrm{IC}_{50}$ value tauco sample is much larger than its peers, namely, vitamin C. Comparison of $\mathrm{IC}_{50}$ values ethanol extract tauco A and B, tauco water fraction, the fraction tauco ethyl acetate, n-hexane fraction tauco, and vitamin $\mathrm{C}$ can be seen in Fig. 3.

Ethyl acetate fraction had the smallest $\mathrm{IC}_{50}$ values between ethanol extract, the water fraction, and the fraction of $n$-hexane of tauco so that it could be said ethyl acetate fraction had good antioxidant activity than the ethanol extract, the water fraction, and the fraction of n-hexane from tauco. Tauco was fermented from soybeans, where soy was known to contain secondary metabolites that isoflavone class of flavonoids. Isoflavones in soy can be found in bound form with sugar (isoflavone glycosides) or in free form (aglycone isoflavones). In the process of fermentation of soy, isoflavone aglycone compound to be transformed into compounds isoflavone aglycone [6]. Therefore, the product of fermentation of soy, isoflavone aglycone is found in large quantities [4]. The antioxidant activity of ethanol extracts tauco not as good as the antioxidant activity of ethyl acetate fraction tauco. When the ethanol extract of hydrolyzed tauco, there will be a breakdown of compounds isoflavone glycosides into isoflavone aglycone and glikosidanya. Compounds isoflavone aglycone this hydrolysis results are less polar solvent that will dissolve in ethyl acetate which is semi-polar. Based on research conducted by Jun et al. [21], the aglycone isoflavones compounds provide better antioxidant activity than the isoflavone compounds in the form of glycosides. Based on research conducted by Hutriadi [5], the aglycone isoflavones compounds contained in tauco are genistein and daidzein, which both of these compounds are known to have antioxidant activity.

The antioxidant activity was shown by $\mathrm{IC}_{50}$ values. An effective antioxidant shown with $\mathrm{IC}_{50}$ values is low. $\mathrm{IC}_{50}$ value is inversely proportional to the antioxidant activity. The smaller the $\mathrm{IC}_{50}$ value, then the ability of antioxidants to reduce free radicals, the better because in low concentrations can inhibit free radicals by $50 \%$. When compared with vitamin $\mathrm{C}$, which have $\mathrm{IC}_{50}$ value of $4.41 \mathrm{ppm}$, the antioxidant activity of ethyl acetate fraction over 163 times weaker than vitamin C. Meanwhile tauco ethanol extract has antioxidant activity 270 times weaker than vitamin C, the fraction of water 395 times weaker compared to vitamin $\mathrm{C}$, and the fraction of $\mathrm{n}$-hexane 418 times weaker than vitamin $\mathrm{C}$. These results, unfortunately, were unexpected. At first place, due to the fermentation process and raw materials of tauco mainly soybeans, it was expected the antioxidant activities of tauco should have high-antioxidant activities. Fidrianny et al. [22] reported in their study of shells extracts of four legumes, soybean, red kidney

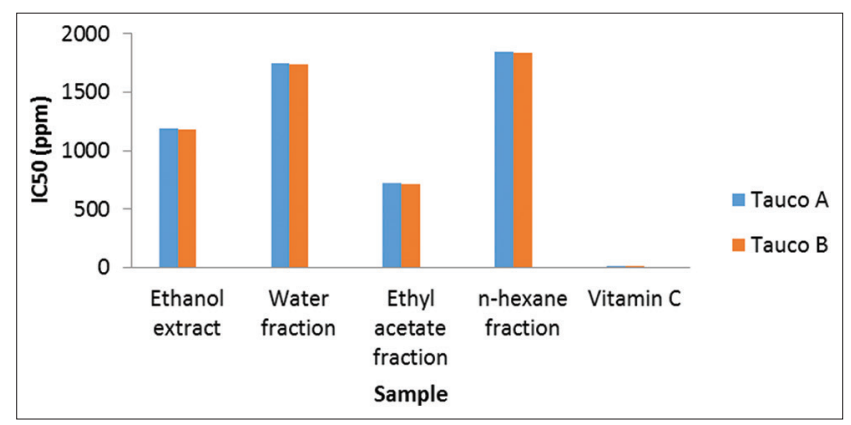

Fig. 3: Comparison inhibition concentration 50 tauco bean, Bogor peanut, peanut, (except n-hexane shells extract of soybean) had $\mathrm{IC}_{50}$ of DPPH scavenging capacities $<50 \mathrm{ppm}$. Most likely, the low antioxidant activities of this report due to tauco process and that soybeans used in these two tauco were mixed beans, not soybeans only.

According to the Jun et al. [21], a compound considered to have a very strong antioxidant activity when have $\mathrm{IC}_{50}$ values of $<50 \mathrm{ppm}$, strong category if you have $\mathrm{IC}_{50}$ values of $50-100 \mathrm{ppm}$, when the medium category have $101-250$ ppm $\mathrm{IC}_{50}$ value, a category feeble have $\mathrm{IC}_{50}$ values $251-500 \mathrm{ppm}$, and was listed inactive when the $\mathrm{IC}_{50}$ values above $500 \mathrm{ppm}$. Based on test results, extracts and fractions of tauco have the ability to neutralize DPPH radical, but the antioxidant activity of extracts and fractions tauco included into the category of inactive because it had $\mathrm{IC}_{50}$ values above $500 \mathrm{ppm}$.

\section{CONCLUSION}

Based on this research, it is known that extracts and fractions of tauco have antioxidant activity with the ability to neutralize free radicals DPPH. Best antioxidant activity of extracts and fractions tauco is shown by ethyl acetate fraction with $\mathrm{IC}_{50}$ value of $722.38 \mathrm{ppm}$ (inactive), followed by ethanol extract with $\mathrm{IC}_{50}$ value of $1192.71 \mathrm{ppm}$ (inactive), the fraction of water with $\mathrm{IC}_{50}$ value of $1746.01 \mathrm{ppm}$ (inactive), and the fraction of n-hexane with $\mathrm{IC}_{50}$ value of $1845.45 \mathrm{ppm}$ (inactive), while vitamin $\mathrm{C}$ have $\mathrm{IC}_{50}$ values are $4.41 \mathrm{ppm}$ (very strong). These results, however, was unexpected that tauco ethanol extract and fractions showed much weaker antioxidant activity than vitamin C. Further research is needed to test the antioxidant activity of tauco using other methods. This will strengthen the scientific data about the antioxidant activity of tauco.

\section{ACKNOWLEDGMENT}

We thank Arina Syifa Hidayati for her technical support.

\section{REFERENCES}

1. Purwaningsih E. Cara Pembuatan Tahu dan Manfaat Kedelai. Bekasi: Ganeca Exact; 2007.

2. Samruan W, Oonsivilai A, Oonsivilai R. Soybean and fermented soybean extract antioxidant activities. World Acad Sci Eng Technol 2012;6(2):1223-6.

3. Pawiroharsono S. Aspek Mikrobiologi tempe. Bunga Rampai Tempe Indonesia. Jakarta: Yayasan Tempe Indonesia; 1996. p. 169-72.

4. Chen TR, Wei QK. Analysis of bioactive aglycone isoflavones in soybean and soybean products. Nutr Food Sci 2008;36(6):540-7.

5. Hutriadi H. Isoflavon Analysis of Tempe and Tauco with High Performance Liquid Chromatography (HPLC), Thesis. Semarang, Indonesia: Diponegoro University; 2001.

6. Pawiroharsono S. Prospek dan Manfaat Isoflavon untuk Kesehatan. Direktorat Teknologi Bioindustri. Jakarta: Badan Pengkajian dan Penerapan Teknol; 2007. p. 27.

7. Hassan N. The Extraction of Antioxidant from Soybean [Thesis]. Malaysia: University College of Engineering and Technology Malaysia; 2006.

8. Figueroa LA, Navarro LB, Vera MP, Petricevich VL. Antioxidant activity, total phenolic and flavonoid contents, and cytotoxicity evaluation of Bougainvillea xbuttian. Int $\mathrm{J}$ Pharm Pharm Sci 2014;6(5):497-502.

9. Winarsi H. Antioksidan Alami dan Radikal Bebas. $5^{\text {th }}$ ed. Yogyakarta: Kanisius; 2007. p. 265-6

10. Fitriani V. Bebas Pilih Atasi Radikal Bebas; 2014. Available from: http://www.lizaherbal.com/main/content/view/169/1. [Last accessed on 2016 Sep 09].

11. Zuhrotun A, Hidayati AS, Mustarichie R, Indriyati W. The antioxidant activity of extract and tauco fraction by DPPH method. In: Proceedings of National Seminar on Health Research and PKM. Vol. 1. p. 2014-9; 2015.

12. Mustarichie R, Indriyati W, Mukmin A, Ramdhani D. Activity of Angiopteris evecta for baldness treatment. J Chem Pharm Res 2016;8(5):821-30.

13. Gatbonton GL, De Jesus AP, Lorenzo KM, Uy MM. Soxhlet Extraction of Philippine Avocadro Fruit Pulp Variety 240. Resarch Congress. De La Salle, University Manila; 2013. 
14. Marnoto T, Haryono G, Gustinah D, Putra FA. Tannin extraction as natural dye from Putrimalu (Mimosa pudica) using organic solvent. Reaktor 2012;14(1):39-45.

15. Departemen Kesehtaan RI. Farmakope Herbal Indonesia. Edisi I. Jakarta: Departemen Kesehatan RI; 2015. p. 17-8.

16. Farnsworth NR. Biological and phytochemical screening of plant. J Pharm Sci 1966;55(3):243-69.

17. Irianti T, Puspitasari A, Suryani E. Radical scavenger activity of 2,2-diphenyl-1-picrylhydrazyl by ethanolic extract of brotowali rod (Tinospora crispa (L.) Miers) and its fractions. Tradit Med Mag 2011;16(3):138-44..

18. Blois MS. Antioxidant determinations by the use of a stable free radical. Nature 1958;181:1199-200.
19. Molyneux P. The use of the stable free radical diphenylpicrylhydrazyl (DPPH) for estimating antioxidant activity. Songklanakarin J Sci Technol 2004;26(2):211-9.

20. Djamil R, Anelia T. Penapisan fitokimia, Uji BSLT, dan uji antioksidan ekstrak metanol beberapa spesies papilionaceae. J Ilmu Kefarmasian Indones 2009;7(2):65-71.

21. Jun MH, Yu J, Fong X, Wan CS, Yang CT. Comparison of antioxidant activities of isoflavones from kudzu root (Pueraria labata Ohwl). J Food Sci 2003;68(6):2117-22.

22. Fidrianny I, Puspitasari N, Singgih M. Antioxidant activities, total flavonoid, phenolic, carotenoid of varoius shells extracts from four species of legumes. Asian J Pharm Clin Res 2014;7(4):42-6. 